Received: November 15, 2017

Revision received: March 22, 2018

\title{
Research on the Factors of Enterprise Education Communication Based on Vertical Integration ${ }^{\star}$
}

\author{
Changwei Zhou ${ }^{1}$ \\ Huaiyin Institute of Technology
}

\begin{abstract}
Education communication is the key of training employees in enterprises. This study uses an integrated framework to explore the effects of organizational factors, individual factors, and educational cognition on educational communication and their processes. Taking 156 educated employees as samples, an empirical study is carried out by means of longitudinal analysis, with the conclusions that the organizational environmental factor enhances the self-efficacy of education and raises the learning orientation and transmission motivation; individual factors have a significant positive impact on educational cognition, which has a significant positive impact on educational communication; educational cognition plays a transformation role between individual factors and educational communication. The results of this study are helpful to deepen the understanding of the law of employee's educational communication behavior, and is of great practical significance to the management practice.
\end{abstract}

\section{Keywords}

Educational Communication $\bullet$ Vertical Integration $\bullet$ Organizational Environment $\bullet$ Individual Factors $\bullet$ Educational Cognition

"This work is supported by the Social Science Foundation of China (17BSH132).

${ }^{1}$ Correspondence to: Changwei Zhou (PhD), Business School, Huaiyin Institute of Technology, Huaian 223001, China. Email: 13429323@qq.com

Citation: Zhou, C. W. (2018). Research on the Factors of Enterprise Education Communication Based on Vertical Integration. Educational Sciences: Theory \& Practice, 18(5), 2266-2273. http://dx.doi.org/10.12738/estp.2018.5.125 
People who work in enterprises generally have some social experience or have received a certain level of education, but the rapid development of modern science and technology has led to the constant adjustment and change of industrial structure. At the same time, people's knowledge structure and skill level should be updated and improved accordingly, so re-education of enterprise personnel is the process of systematic and planned change of knowledge, skill and behavior.

The present research discusses the influencing factors of educational communication effect from the aspects of employee characteristics, educational design and organizational environment. Govaerts, Kyndt, Vreye, \& Dochy (2018) believes that behavior and attitudes are the main factors that enhance the education communication among employees, and that emphasis should be placed on the communication of educational capacity to jobs. Kreuzer, \& Weber (2018) think that due to the tremendous changes in the world, companies and employees need innovative thinking to cope with modern challenges, and through the integration of educational communication ability model, education communication can continue enterprise innovation. Jaworski, Ravichandran, \& Karpinski (2018), Qudah, Yang, \& Alsaidan (2018), and Law, Hills, \& Hau (2017) think that educational communication integration can influence employees' job satisfaction and loyalty, so as to promote the employee's organizational commitment to the sustainable development of the enterprises. Gayed et al., (2018) believes that educational communication affects the mental health and well-being decision of employees. Felli, \& Harris (2018) studied the advantages of the integration of educational communication under market regulations, and found the reasons for the inefficiency of the accelerated productivity enhancement model and the accelerated learning model. Drange, Bernstrom, \& Svenn-Erik (2018) discusses that education communication and the development of employer's ability determine the employee's expectation of maintaining employment and career development, and finds that the matching of education communication is the most important to maintaining the expectation of employment. Lundkvist, \& Gustavsson (2018) believes that innovation in employee education must take different forms and involve functions that support innovative learning, which are not just minor adjustments to existing production standards, but also new requirements for managing high-level skills in order to promote productive capacity. Van Praag, van Witteloostuijn, \& van der Sluis (2013) discussed the importance of formal education to entrepreneur income and employee value.

This research attempts to establish a vertical integrated analysis framework, adopts vertical research and design, and uses empirical model to systematically explore the possible interaction between excellent organization and management support with employees' self-efficacy, learning orientation, dissemination motivation and educational communication behavior, which will help to deepen the understanding of the dynamic process law of employee education communication.

\section{Theoretical Hypotheses}

The expression of education communication mainly lies in the communication intention and behavior of the educated staff. There are many factors that affect the educational communication behavior of employees, mainly including organizational factors, individual factors, educational cognitive process and so on. 


\section{Role of organizational factors on individual factors}

(1) Effect of excellent organization on individual factors

The educational effect is the degree of self-confidence that the employees use their self-skills to succeed in education and improve their ability. It is the result of weighing and evaluating the self-ability information. When the employees feel that they are in a superior environment, they will have a higher level of self-efficacy and transmission motivation. Learning orientation originates from the theory of achievement motivation, and the formation of educational motivation is a process of developing action intention. Employees will consider whether the organization is worth paying. The transmission motivation is that the educated employees intend to apply their learnt knowledge and skills to the actual work, believe and accept the development goals and values of the enterprise, and are willing to generate higher psychological commitment to the enterprise and pay more efforts to achieve organizational goals and personal promotion goals.

Hypothesis 1 is hereby put forward:

Excellent organizations are positively related to educational effect, learning orientation and transmission motivation.

(2). Effect of high-level opportunity factor on individual factors

The higher level provides the proper guidance for the educated staff in the daily life and strengthen the opportunities to use what they have learned, so they will have the positive influence to the educated staff's selfefficacy, learning direction, transmission motivation and other individual factors, thus promoting the long-term education communication behavior.

Hypothesis 2 is hereby put forward:

High-level opportunity is positively related to educational effect, learning orientation, and transmission motivation.

\section{Individual factors and the process of educational cognition}

Educational cognition is the process of the educated staff thinking about the absorption and application of the specific knowledge and skills obtained from education, and it is the process of psychological construction that connects educational curriculum and communication strategy, showing individual differences.

Hypothesis 3 is hereby put forward:

Self-efficacy, learning orientation, transmission motivation and educational cognition are positively correlated.

\section{Educational cognition and educational communication}

Education communication is a process in which the employees continuously transmit the education income to the real work and process. The process of educational cognition, which is a systematic thinking on how to apply the education content and educational outcome, belongs to the category of self-management, so it will 
Zhou / Research on the Factors of Enterprise Education Communication Based on Vertical Integration.

promote the effective connection between education and daily work and enhance the effect of educational communication.

Hypothesis 4 is hereby put forward:

There is a positive correlation between educational cognition and educational communication.

Educational cognition may also be the transformation variable between individual factors and educational communication. The cognitive understanding of the educated staff on educational content and educational communication strategies will further strengthen the positive effect of the individual characteristics of the educated staff on the educational communication.

Hypothesis 5 is hereby put forward:

Educational cognition is the transformation variable of educational effect, learning orientation, transmission motivation and education communication.

\section{Research Contents}

\section{Research object and questionnaire collection}

Research object of this questionnaire is 5 companies in Nanjing, the investigation time starts in August 2017 and ends in December 2017. 23 invalid questionnaires are found through manual screening. After eliminating the invalid questionnaires, 156 effective questionnaires are collected, with an effective recovery rate of about $87 \%$.

\section{Research variable measurement}

The research variables are all measured according to the relevant research, with the scale verified by the reliability and validity. The measuring tools for each variable are as follows:

(1) Excellent organization, defined as "when I have a problem, I can get the help of education from the organization", and the internal consistency coefficient of the scale is 0.91 , with good measurement reliability (the general data is 0.70 ).

(2) High level opportunity, defined as "the high level gives me the opportunities to use the skills I have learned in education", and the internal consistency coefficient of the scale is 0.85 .

(3) The educational effect, defined as "I want to do well when I receive the education in unfamiliar areas", and the internal consistency coefficient of the scale is 0.90 .

(4) Learning orientation, defined as "I have learned as much as possible from education", and the internal consistency coefficient of the scale is 0.92 .

(5) Transmission motivation, defined as "I believe that if I use the knowledge and skills I have learned from education, my performance will be enhanced and improved", and the internal consistency coefficient of the scale is 0.84 . 
Zhou / Research on the Factors of Enterprise Education Communication Based on Vertical Integration.

(6) Educational cognition, defined as "I think about how to achieve the educational goal after education", and the internal consistency coefficient of the scale is 0.91 .

(7) Education communication, defined as "by the use of new knowledge learned from education, I improve the performance of my work", and the internal consistency coefficient of the scale is 0.82 .

\section{Research method}

Firstly, SPSS is used for statistical analysis of descriptive statistics, correlation and internal consistency reliability. Secondly, LISREL model is adopted to verify the influence direction and effect of each variable in the theoretical framework, so as to test the correctness of hypotheses and judge the conversion effect of educational cognition. Finally, three conditions must be satisfied: the independent variable is related to the transformation variable; transformation variables are related to dependent variables; when there is a conversion variable, the correlation between the independent variable and the dependent variable decreases, and even becomes insignificant.

\section{Empirical Analysis}

\section{Descriptive statistics}

Table 1 shows the mean, standard deviation and Pearson correlation analysis results for each research variable. In the aspect of correlation analysis, the results show that excellent organization has a significant positive relationship with educational effect and transmission motivation $(r=0.39, \mathrm{p}<0.01 ; \mathrm{r}=0.31, \mathrm{p}<0.01)$; the higher level opportunity has a significant positive relationship with the education effect, learning orientation, and transmission motivation $((\mathrm{r}=0.62, \mathrm{p}<0.01 ; \mathrm{r}=0.54, \mathrm{p}<0.01 ; \mathrm{r}=0.58, \mathrm{p}<0.01)$; educational cognition has a significant positive relationship with self-efficacy, learning orientation and transmission motivation ( $\mathrm{r}=0.61$, $\mathrm{p}<0.01 ; \mathrm{r}=0.58, \mathrm{p}<0.01 ; \mathrm{r}=0.53, \mathrm{p}<0.01)$; and educational cognition has a significant positive correlation with educational communication $(r=0.49, \mathrm{p}<0.01)$. The relationship among research variables is basically consistent with the expected direction of the study as shown in Table 1.

Table 1

Expected Direction of Relationship Among Research Variables

\begin{tabular}{|c|c|c|c|c|c|c|c|c|c|c|}
\hline NO. & Variables & Average & $\begin{array}{l}\text { standard } \\
\text { deviation }\end{array}$ & 1 & 2 & 3 & 4 & 5 & 6 & 7 \\
\hline 1 & $\begin{array}{l}\text { excellent } \\
\text { organization }\end{array}$ & 3.58 & 0.72 & 0.91 & & & & & & \\
\hline 2 & $\begin{array}{l}\text { higher level } \\
\text { opportunity }\end{array}$ & 4.12 & 0.61 & 0.21 & 0.85 & & & & & \\
\hline 3 & education effect & 4.05 & 0.55 & 0.52 & 0.68 & 0.90 & & & & \\
\hline 4 & learning orientation & 4.29 & 0.81 & 0.19 & 0.32 & 0.28 & 0.92 & & & \\
\hline 5 & $\begin{array}{l}\text { transmission } \\
\text { motivation }\end{array}$ & 4.21 & 0.62 & $\begin{array}{l}0 . \\
41\end{array}$ & 0.38 & 0.37 & 0.41 & 0.84 & & \\
\hline 6 & $\begin{array}{l}\text { educational } \\
\text { cognition }\end{array}$ & 3.90 & 0.43 & 0.34 & 0.41 & 0.48 & 0.52 & 0.56 & 0.91 & \\
\hline 7 & $\begin{array}{l}\text { educational } \\
\text { communication }\end{array}$ & 3.76 & 0.71 & 0.32 & 0.23 & 0.38 & 0.30 & 0.56 & 0.52 & 0.82 \\
\hline
\end{tabular}

Note. * represents $\mathrm{p}<0.05$, ** represents $\mathrm{p}<0.01$, the same below; the last number of diagonals is the internal consistency reliability coefficient of the scale. 


\section{Model fitting and hypothesis testing}

The $X^{2}(\mathrm{df}=10)$ value of the hypothesis-based theoretical model is $20.15(\mathrm{p}<0.01)$, which is significant, indicating that the theoretical model is poorly matched with the observed data. The fitting index values of $\mathrm{X}^{2} /$ df, GFI, NFI, NNFI, IFI and CFI are 3.12, 1.13, 1.05, 1.13, 1.18 and 1.12, respectively, and each index can meet the standard, while RMS R $=0.13$, which fails to meet the standard, so there is still room for improvement in the model. According to literature research, there may be a direct connection between educational effect, transmission motivation and educational communication, while learning orientation focuses on educational learning process, and is more likely to be connected with educational communication through educational cognition. Therefore, it is assumed that educational cognition only plays a part in the transformation between individual attribute factors and educational communication. Therefore, based on the above considerations, this research modifies the model, increases the direct action path of educational effect and transmission motivation on educational communication, and constructs a partial transformation action model.

The modified model shows a better fitting, where the value of $X^{2}(d f=8)$ is $10.26(p<0.20)$, which is not significant, indicating that the modified model matches the observed data; the fitting index values of $\mathrm{X}^{2} / \mathrm{df}$, GFI, RMSR, NFI, NNFI, IFI and CFI are 1.33, 0.86, 0.12, 0.87, 0.83, 1.01 and 0.86, respectively. All the indexes can meet the standard, so the fitting degree of the model is very good.

Table 2

Path Coefficients and Test Results

\begin{tabular}{lcc}
\hline Hypothesis & Coefficient & Test results \\
\hline H1.1: excellent organization-education effect & $0.28^{* *}$ & support \\
H1.2: excellent organization-learning orientation & -0.04 & nonsupport \\
H1.3: excellent organization - transmission motivation & 0.13 & support \\
H2.1: higher level opportunity-education effect & 0.51 & support \\
H2.2: higher level opportunity-learning orientation & 0.41 & support \\
H2.3: higher level opportunity-transmission motivation & 0.51 & support \\
H3.1: education effect-educational cognition & 0.22 & support \\
H3.2: learning orientation-educational cognition & 0.25 & support \\
H3.3: transmission motivation-educational cognition & 0.18 & support \\
H4: educational cognition-educational communication & 0.35 & support \\
H5.1: education effect-educational communication & 0.23 & support \\
H5.2: learning orientation-educational communication & 0.08 & support \\
H5.3: transmission motivation-educational communication & 0.25 & nonsupport \\
\hline
\end{tabular}

The chi-square test is used to compare the modified model with the original model. The results show that there is a significant difference in the $X^{2}$ value between two models $\left(\Delta X^{2}\right.$ is 11.52 and $\left.\triangle \mathrm{df}=0.8, \mathrm{p}<0.01\right)$, indicating that the modified model is superior to the original model, so the modified model can be used to determine the relationship among the variables, as shown in Table 2.

(1) Test of H1. In this research, latent variable path analysis is used to verify the relationship between excellent organizations and individual factors. Excellent organizations have a significant positive effect on educational effect and transmission motivation, and the path coefficients are $0.28(\mathrm{p}<0.01)$ and $0.13(\mathrm{p}<0.01)$ respectively, while excellent organizations have no significant effect on learning orientation. Therefore, H1 is supported partly. 
Zhou / Research on the Factors of Enterprise Education Communication Based on Vertical Integration.

(2) Test of H2. High level opportunity has significant positive effects on the educational effect, learning orientation and transmission motivation, and path coefficients are $0.51(\mathrm{p}<0.01), 0.41(\mathrm{p}<0.01)$ and $0.51(\mathrm{p}<$ 0.01 ), respectively. Therefore, $\mathrm{H} 2$ is supported by empirical evidence.

(3) Test of H3. The educational effect, learning orientation and transmission motivation have significant positive effects on educational cognition, and path coefficients are $0.21(\mathrm{p}<0.01), 0.25(\mathrm{p}<0.01)$ and $0.18(\mathrm{p}$ $<0.01$ ), respectively. Therefore, H3 is supported by empirical evidence.

(4) Test of H4. Educational cognition has a significant positive effect on educational communication, and the path coefficient is 0.35 ( $p<0.01$ ), so H4 is supported by the empirical study.

(5) Test of H5. In accordance with conversion effect test method, the independent variables such as education effect and transmission motivation are significantly positively related to education communication, but in the modified model of the conversion variable-education cognition, the education effect and transmission motivations are still significantly related to education communication (path coefficient is 0.23 and 0.25 , respectively), so education cognition is not the transformation variable of education effect, transmission motivation and education communication. According to the existing research literature, learning orientation has no direct effect on education communication, and only through educational cognition can it have a positive effect on educational communication, with the indirect effect coefficient of 0.11 . Therefore, H5 is partially supported.

\section{Conclusions and Suggestions}

First, excellent organizations have positive influence on self-efficacy and transmission motivation of the educated staff, but have no significant influence on learning orientation; the high-level opportunity has a positive effect on the self-efficacy, learning orientation and transmission motivation of the educated staff. The most basic level of support that organizations can provide is to allow and encourage employees to participate in education, give them practical opportunities to strengthen the application of the skills they have learned, and promote mutual discussion, timely communication and solution of practical problems. Second, the self-efficacy, learning orientation and transmission motivation of the educated staff have a positive influence on the educational cognition, and the cognitive thinking on the application of educational knowledge is the pre-variable of the effectiveness of educational communication. Thirdly, it is suggested that enterprises make appropriate integration and arrangement on the education program, and increase the combination of the education situation and the real working environment by providing meaningful materials and memory skills to the educated staff, in order to enable employees to perform a rapid cognitive transformation based on the stored educational information in the future programmed work or in a sudden situation. Fourth, improve the enterprise education system, to solve various problems in the introduction of the frontline employees, and to ensure the effectiveness of education communication. 


\section{References}

Drange, I., Bernstrom, V. F., \& Svenn-Erik, M. (2018). Are you moving up or falling short? An inquiry of skills-based variation in self-perceived employability among Norwegian employees. Work Employment and Society, 32(2), 387-406.

Felli, L., \& Harris, C. (2018). Firm-specific training. Journal of Economic Theory, 175, 585-623. http://dx.doi.org/10.2139/ssrn.259248

Gayed, A., Milligan-Saville, J. S., Nicholas, J., Bryan, B., LaMontagne, A. D., Milner, A., Madan, I., Calvo, R. A., Christensen, H., Mykletun, A., Glozier, N., \& Harvey, S. B. (2018). Effectiveness of training workplace managers to understand and support the mental health needs of employees: A systematic review and metaanalysis. Occupational and Environmental Medicine, 75(6), 462-470. http://dx.doi.org/10.1136/oemed2017-104789

Govaerts, N., Kyndt, E., Vreye, S., \& Dochy, F. (2018). A supervisors' perspective on their role in transfer of training. Human Resource Development Quarterly, 28(4), 515-552. http://dx.doi.org/10.1002/hrdq.21286

Jaworski, C., Ravichandran, S., \& Karpinski, A. C. (2018). The effects of training satisfaction, employee benefits, and incentives on part-time employees' commitment. International Journal of Hospitality Management, 74, 1-12.

Kreuzer, C., \& Weber, S. (2018). Modelling opportunity recognition competence as a foundation for teaching and learning in vocational education. Vocations and Learning, 11(3), 399-423. http://dx.doi.org/10.1007/s12186-017-9194-7

Law, M. M. S., Hills, P., \& Hau, B. C. H. (2017). Engaging employees in sustainable development-A case study of environmental education and awareness training in Hong Kong. Business Strategy and the Environment, 26(1), 84-97.

Lundkvist, A. H., \& Gustavsson, M. (2018). Conditions for employee learning and innovation - Interweaving competence development activities provided by a workplace development programme with everyday work activities in SMEs. Vocations and Learning, 11(1), 45-63. http://dx.doi.org/10.1007/s12186-017-9179-6

Qudah, N. F. A., Yang, Y., \& Alsaidan, S. (2018). Transformational training programs and quality orientation of employees: Does employees' loyalty matter?. Sustainability, 10(2), 465. http://dx.doi.org/10.1007/978981-13-1059-1_38

Van Praag, M., van Witteloostuijn, A., \& van der Sluis, J. (2013). The higher returns to formal education for entrepreneurs versus employees. Small Business Economics, 40(2), 375-396. http://dx.doi.org/10.1007/s11187-012-9443-y 